\title{
Various Aspects of the Multipolarity within the World Economic System
}

\author{
Alexey Y. Arkhipov
}

Higher School of Business, Southern Federal University, Rostov-on-Don, Russia, 23 line, 43, 344019, Rostov-on-Don, Russia

Email: arkhipov@sfedu.ru

Alexey N. Yeletsky

Higher School of Business, Southern Federal University, Rostov-on-Don, Russia

\section{Doi:10.5901/mjss.2015.v6n3s6p59}

\begin{abstract}
The key aspects of the world economy's transformation in the context of the multipolar world formation are studied in the article. Various kinds of economic multipolarity are analyzed. There is specially emphasized the wide range of multipolarity's forms except the classical form concerning the competitive interactions of great powers. The particular role of financial and industrial sectors in the formation of the "branch growth poles»is considered in detail. Specific attention is paid to the growing influence of the regional leaders and strengthening positions of developing countries within the world economic system. The reinforcing influence of the regional and transregional integration groups is underlined. The key economic tendencies concerning the vectors of reshaping of the world geo-economic alignment of forces in the nearest future are examined in the article. There is also demonstrated the global economic and political reluctance of developed countries (especially Anglo-Saxon ones) to the objective process of a gradual dispersal of geo-economic influence within the world economy.
\end{abstract}

Keywords: multipolarity, global leaders, world economic prospects, developing countries, regional leaders

\section{Introduction}

The last decades marked a significant change in the world economy characterized not only by the intensification of the key world economic tendencies, such as globalization and internationalization, but also by the transformation of the geoeconomic leadership's polarity. Just as the collapse of the Soviet Union designated the end of the bipolar economic and political order, the recent global financial and economic crisis became the catalyst of the processes forming geoeconomic multipolarity. The relevance of this topic is conditioned not only by a global range of processes involving all actors of the global economic system, but also by depth and ambiguity of the multipolarity. Definitely, it should be noted that the most important aspect of the economic multipolarity is connected with the rise of new global economic leaders, or entire integration groups which are becoming increasingly important participants of the international division of labor and geopolitical processes. The countries-leaders (first of all, China and other BRICS countries) and the most advanced economic unions (e.g., EU) actively reshaped the world economic system and created competition with the USA and its Anglo-Saxon allies. At the same time, along with the global powers' multipolarity, there are other forms of economic multipolarity. For example, the rise of developing countries has also led to the formation of branch multipolarity, as the developed countries no longer dominate in many industrial and post-industrial areas. However, modern transformation of the world economy towards the postindustrial structure of the economy allowed restoring some former influential powers among the developed countries. The most striking example is the United Kingdom. It is also important to point out the growing potential of some regional leaders under conditions of economic multipolarity. Moreover, some of them have potential to rise as new centers within the emerging economic and political configuration of the XXI century.

\section{Evolution of the World Economic and Political Order}

The presence of power centers and the dynamics of their interaction are significant characteristics of the global economy. Under modern conditions the very concept of polarity within the global world is changing. The poles of its development have become increasingly multi-layered and multi-valued. Along with the traditional economic and political polarity, the role of the poles as "growth poles" in various spheres of social reality has formed, and the functional and branch "growth 
poles" appeared. Their evolution is changing the face of the modern world. A peculiar global and regional dualism has been demonstrated by many countries that are continental and subcontinental leaders. Understanding the poles as "growth poles" of the modern civilization makes necessary the analysis of ambiguities and contradictions of the world multipolar structure.

There are known different periods of the geo-economic leadership within the world economy. Historically some periods were characterized by the dominance of one power or, on the contrary, by the presence of several or even many centers of economic and political influence. As a result of the World War II there were two economic and political poles which determined the global confrontation during the second half of the twentieth century. The Soviet Union and the United States were the leading economies of the world, and the Soviet economy made up $75-80 \%$ of the American one, which allows us to approximate the comparability of the economic potentials of the two superpowers. In addition, the opposing poles were the main military, political, scientific, technological, ideological centers, which headed their own political and economic blocks, while a large part of the non-aligned countries was determined by rather neutral term "the Third World".

The collapse of the bipolar world order has radically transformed the status of the geo-economic system. In 1990s and early 2000s the trend of unipolar globalization began to prevail. The unconditional economic and political dominance of the Western world led by the United States manifested itself in the propagation of so-called "Washington consensus" together with widespread standpoints about the "End of history".

However, nowadays the geo-economic structure of the modern world is changing dramatically. The unreserved economic and political predominance of the United States and other Western highly developed countries has been considerably undermined by the high growth of Newly industrialized and "new waves" of other developing countries. Without any doubt, China and BRICS countries have considerable role regarding the reshaping of the world geoeconomic order. New economic and political poles began to form. Thus, modern economic and political balance can be characterized by global uncertainty of further development's vectors of the modern geo-economic space. Besides, the role of global economic trends like globalization and internationalization continue strengthening.

\section{Reinforcement of the Multipolar Tendencies}

\subsection{The rise of developing economies}

Recent global financial and economic crisis has become an additional catalyst in the emerging processes of redistribution of the forces in the world economy. It is necessary to mention that during the world economic crisis one could finally speak of the formation of the future multipolar world's contours of the XXI century. As noted by Z. Brzezinski in his wellknown work "Strategic vision: America and the crisis of global power", one of the main features of the modern state of the world's economic and political configuration is the growing "dispersal of geopolitical power" (Brzezinski, 2012). As for the economic aspect, this period is characterized by significant increase in mutual trade among developing countries, whose total share in the international trade reached $42 \%$ in 2010 . It is noteworthy that the share of developing countries makes up about $75 \%$ of official gold and foreign exchange reserves, while in 1990s two-thirds of the reserves were owned by developed economies (International Bank for Reconstruction and Development, 2012). In 2010, China had already taken the first place on industrial output. In addition, the risks of investing in the so-called "emerging markets" have decreased significantly, which resulted in a significant inflow of foreign investment in the leading developing countries, primarily China, India and Brazil. In addition, the BRICS countries, as well the CIS have made decisions concerning the use of their own currencies for mutual payments, which mark the gradual weakening of the dollar's comprehensive predominance. As for the forecasts of the future economic development such countries as China, India, Brazil, Indonesia, South Korea and Russia will presumably amount more than half of the total growth in the world GDP by 2025. Besides, China's GDP will exceed US one by 2020 (moreover, according to IMF latest projections Chinese GDP (PPP) overtook American figures in 2014) (International Monetary Fund, 2014), while GDP of developing countries will surpass GDP of the developed ones by 2017 (Vasilyeva, 2013). Such dynamics of economic growth allows predicting that not only BRICS countries, but also South Korea, Indonesia and Turkey will take their place in the list of the largest economies of the world in the coming decades.

In addition to the state "dimension" of the global geo-economic and geopolitical multipolarity, one can note the increasing role of integration blocks in the tendencies of regionalization. In the XIX century in the framework of the National system theory, German economist F. List emphasized a greater stability and competitiveness of the largest economically integrated associations. According to some modern scholars, it is integration groupings (the EU, NAFTA, MERCOSUR with its military-political superstructure of UNASUR, ASEAN, the Eurasian Union which will constitute the 
basis for a multipolar world of the XXI century.

In these conditions modern EU crisis is probably an echo of confrontation between unipolar and multipolar trends in the world (Gulevich, 2012). On the one hand, the EU countries are the major economic partners of the United States, as well as American partners within NATO, and in this regard they have common ground and cooperation in expansionist actions in the Arab world. On the other hand, such a powerful regional economic Union with the currency component in the form of the Eurozone is showing increased willingness and inclination towards supranational political Union: from the draft of the European Constitution to adoption of the Lisbon Treaty and formation of a new Budget and Fiscal Pact. This greatly worries the US with the striving for utter unchallenged currency hegemony, economic superiority and definitely extreme interest in a maximum involvement in European affairs, that is, in maintaining political control over Europe.

\subsection{Formation of the multipolarity in different sectors}

Nowadays there is a process reshaping the internal structure of the key developing countries' economies, including strengthening the position of the processing industry, machinery, high-tech industries in the structure of GDP and, consequently, the high-tech export and the growth of spending on research and development. Similar trends point out both quantitative and qualitative transformations in the world economy and reveal another form of economic multipolarity - branch multipolarity. Previously, the country's active participation in the production and international trade in manufacturing goods with high added value, as well as strong positions in key services sectors were the prerogatives of the leading developed Western countries. Currently, the largest developing countries and NIC decisively entered the ranks of the leading industrial, technological and financial powers of the world.

The indisputable leader among them is certainly China. The positions of other BRICS countries such as India, Russia, Brazil and South Africa are strengthening steadily. For example, Brazil has made significant advances in civil and military aircraft industry, and its aerospace company "Embraes" contests the third place in the world production of civil aircraft with the Canadian "Bombardier", followed by only two aircraft giants: "Boeing" and "Airbus". Objective dying-out of a unipolar geo-economic structure lays foundations of multipolarity in the context of globalization processes in modern society. In the financial sector the formation and strengthening of new international financial centers are increasingly obvious. Today dynamic East presses leading centers in the ranking of the main economic leaders. So, besides London and New York, Hong Kong, Singapore and Shanghai have appeared in the rating of the top five largest financial centers (Khudyakova, 2012). In addition, there are favorable prospects for strengthening new financial centers such as Dubai, Mumbai and Sao Paulo. It is also known that several years ago Russian authorities also declared creation of an international financial center in Moscow.

\subsection{Postindustrialization as a factor of British power's renaissance}

Financial and information spheres play a dual and contradictory role in the modern world economy. On the one hand, it is important to note that the hypertrophied growth of the financial industry and its detachment from the real sector of economy have recently led to significant imbalances of the world economic system, having appeared one of profound and underlying causes of the global economic crisis. Moreover, the existing imbalance between the volume of real and financial-speculative sectors tends to further strengthening, making this issue one of the global problems of the modern world economy. On the other hand, financial and speculative sector is a doubtless point of growth in the global economy. This sector has gained its particular importance under conditions of post-industrial information society. The importance of an intermediary role of Great Britain has been increasing constantly for the last decades. This specific role was to a great extent caused by post-industrial transformation of the global economy. From the so-called "sick man of Europe" - the country with stagnating traditional industrial branches, depressive areas and numerous strikes of workers during the Winter of Discontent - Great Britain turned into one of the leaders of global information revolution and the center of regulation of world economic communications. The British role was pushed up by the fast strengthening of financial sector of the world economy over the real one. Along with globalization of the world economic information, computerization and Internet development this process led to sharp strengthening of London as a global information financial center and one of key elements within Anglo-Saxon system, and, probably, the most important element regarding financial regulation (Khudyakova, 2012). "New York is considerably behind London in trade of securities of foreign issuers and operations with international assets of banks... The vast majority of researchers distinguishes a triumvirate of the major financial centers of the world: London, New York, Tokyo - with the leading role of the capital of Great Britain ... According to TeleGeography company, considering only international traffic which passes on international backbones, the largest hub of the Internet is London (1,1 Tbit / with; peak load - $439 \mathrm{Gbit} / \mathrm{c}$ ), and the main 
route - London - New York (320 Gbit / c; peak load - 153 Gbit / c)" (Sluka, 2008).

One of the key dynamic indicators of the modern globalizing society is an increasing business mobility. According to this indicator, London is also the leader in the world - the annual aviation passenger traffic of London's hub makes up 125 million people, while in New York - 100 million, in Tokyo - 90, in Paris - 80 million (Sluka, 2008). Thus, it is quite possible to state that the purpose which had been formulated by M. Thatcher - "We will make Britain great again" became completely achievable in a new global post-industrial transformation. Due to considerable financial flows and increased investment attractiveness, the UK has increased its military expenditures and gradually strengthened its position in the world. Victorious Falkland War can unanswerably be considered as a manifestation of this tendency. After almost forty years of an absolute Soviet-American political dominance on the political horizon there emerged the power capable of protecting its own economic and political interests under conditions of restraint and dissociation of both superpowers. In 1990-2000-s the United Kingdom confirmed and strengthened its status of the most important American ally in the framework of the concept of "Special Relationship" between the two related states and played a significant role in Afghan and Iraqi campaigns. In addition, the overall increase of England role in the world economic and political system in general, and in Anglo-American relations in particular, allows us to speak about two main poles of the AngloSaxon world or Anglosphere, sometimes referred to as "the Anglo-Saxon Empire" (which also includes other developed British resettlement colonies - Canada, Australia, New Zealand and, partly, Ireland). It is significant that in the conditions of transition towards new global information method of production consolidation and unity of the new Anglo-Saxon Empire have shown themselves exactly in the information sphere. And the leadership in this aspect can be correlated with the role of Britain, which, for example, was demonstrated by recent events concerning Snowden's revelations.

Another example of functional and sectoral pole of growth in the modern world is the Internet business. Under modern conditions this sector also demonstrates economic multipolarity. It is important to note that Russia has become an important actor in this field. So, by 2012 the share of Internet business in the Russian GDP exceeded 4.5\%. The most important markets of Internet business in Russia still include Internet commerce, e-payments, video advertising. Many Russian companies successfully compete with foreign ones. For example, at the beginning of 2013 "Yandex" (the search engine) had become the fourth in the world according to the number of requests. In general the prospects for the Russian Internet business in the context of the global Internet market are evaluated very positively. Russian Internet market is the fifth in the world, and it is the most rapidly growing on the planet. Thus, the sphere of information technologies is also a good example of branch multipolarity within the world economic system.

\section{Regional Powers within the Multipolar Geo-Economic Order}

\subsection{Poland as a regional power of Central-Eastern Europe}

It is necessary to notice that under conditions of global uncertainty along with the global geo-economic leaders and centers of a multipolar world, many regional powers are also rising. As a rule, these states have considerable economic progress, their own industrial base and developing financial sector, relatively skilled manpower, comparative military power and their own sphere of geo-economic influence. So, one of successfully developing countries, actively claiming the role of regional leadership in the world economy, is Poland. During the transitional economic period a certain number of important reforms was held, and finally, Poland joined the European Union in 2004.However, even in the first half of the 1990-s Poland has proved to be the leader of the Visegrad Group established as a necessary one during transitional period for the four Eastern European states before their admission to the EU. It is obvious that after the admission to the EU, the Polish economy has retained a number of difficulties, traditionally characteristic for the countries with transition economies (Kondratov, 2012). Nevertheless, Poland has achieved a significant progress in the transformation of its economic system. In 2009 at the peak of the global economic crisis, it has become the only country in the whole Europe, which didn't turn into recession. However, the rate of its economic growth reduced to $1.8 \%$. In general, during the last ten years Poland advanced from the 24th to 20th position in the ranking of countries by GDP calculated on the basis of purchasing power parity. During this period Poland surpassed such countries as Thailand, Argentina and the Netherlands. In 2011 the real GDP rate of growth was 4.3\%, although economic growth has declined in 2012 because of reduction in the Polish exports and the problems of the Euro zone, with which Poland has a high level of interdependence. However, the main strategic goal of the Polish economic policy is to join the Euro zone. The aspiration to intensify these processes is constantly declared by Polish authorities. At the moment Poland is expected to join the Euro zone by 2015, with a simultaneous introduction of Euro in cash and non-cash payments. Another important aspect of the Polish economic ambitions is the attempt to establish a regional financial center in Warsaw. It should be noted that there are positive preconditions for successful realization of this idea in the future. Nowadays Poland is not only the 
largest economy of the region, attracting significant investment flows (mainly from the EU member states), but it also demonstrates the significant positive dynamics in providing various financial services. The zloty is also relatively stable and respectable local currency. It is noteworthy that the credibility of the Polish financial system increases not only in the countries of Visegrad region, but also in the former Soviet republics, including the Ukraine. Russia also emphasized the possibility of creating an international financial centre in Moscow, but after the onset of the global crisis these intentions were overshadowed by the important internal issues. It can be predicted that the struggle for the status of the leading financial center in Eastern Europe between Moscow and Warsaw is ahead.

Nowadays the role of Poland as the strongest U.S. ally in Eastern Europe is, without any doubt, significant. Poland was the most ardent supporter of the "Orange Revolution" in the Ukraine, the most loyal ally of Georgia in its anti-Russian ventures and active supporter of admitting some post-Soviet states to the the EU and then NATO. Poland plays the specific role in the development of the "Eastern partnership" as a transitional stage for a number of states in their striving for European integration. It is obvious that Poland regards the Ukraine and Belarus as a paramount field of geopolitical struggle with Russia.

At the same time, the Polish geopolitical ambitions for the regional leader were implemented with the creation of Visegrad Group in 1991. This form of internal regional integration hasn't lost its importance even after admitting these countries to the EU. So, at the summit in Prague in June 2012 important decisions were taken regarding the common military policy. Firstly, four countries have agreed on the establishment of a joint military unit under Polish command by 2016. Moreover, there are plans for far-reaching large military orders. In addition to the military-political cooperation, Visegrad Four also noted the particular relevance of the energy security of the region. That means a determined attempt to reduce dependence on the import of Russian hydrocarbons (Gulevich, 2012). However, in spite of the cultural and historical closeness of the Eastern European group of four together with the obvious superiority of Poland in population, GDP and other important indicators defining the power of a country, the Polish claim on the role of the regional leader often encounters a serious opposition, especially from the Czech Republic.

Thus, it can be noted that the prospects of Poland as a strong regional power in the modern multipolar world are rather favorable. During the last twenty years Poland experienced rather significant economic and geopolitical advance, successfully overcame negative aftereffects of the global financial crisis and strengthened its influence on European political and economic events. It should be noted thatpragmatic course of Polish government plays important role in the Polish successes of the past few years. Beyond all doubt, Polish authorities realize huge opportunities for the Polish Republic under the current conditions of world economy's reshaping and the global economic and political uncertainty.

\subsection{Turkey: the key geo-economic Eurasian power}

Turkey is another remarkable representative of dynamically developing countries, which has demonstrated a significant increase in economic and political influence and emerged as a strong regional power. A decade of Justice and Development Party, led by R. Erdogan, can be characterized as crucial in several respects. Firstly, it should be noted that economic success demonstrated by Turkey in this period, is undoubtedly prominent. This progress transformed Turkey from a country with a stagnant economy, high level of corruption and a relatively low standard of life into one of the most dynamically developing countries of the world. Turkey is currently in the 16th place in the rating of leading economies of the world in purchasing parity power terms, whereas 10 years ago it was in the 21-th position. Moreover, according to economic forecasts, taking into account the current state of the Turkish economy, Turkey should join the ten leading countries in GDP by 2023 (Chaumet, 2013). It can be noted that in contrast to the classical European countries (including Russia), where the demographic processes are characterized by an ageing population and low birth rate, Turkey with a population of 80 million people demonstrates a high rate of population growth - 1,36\% per year. If in 1970 the population of this country was only 35 million, it has more than doubled in the last forty years (Université de Sherbrooke, 2013).

In addition to purely economic success (that is clearly a significant achievement itself), in recent years Turkey has increasingly demonstrated its growing geopolitical and geo-economic ambitions. The course pursued by the current Turkish government, speaks about the formation of a "neo-ottoman" policy of Turkey. Of course, we are not talking about the restoration of some kind of imperial control over the vast territories that were once controlled by the Turks, but about strengthening Turkish geo-economic power in these regions. So, in the post-Soviet space the role of Turkey in the Russian-American geopolitical conflict in Georgia in 2008 is quite remarkable: the Turkish government, has not allowed the NATO partners to enter the Black Sea by large naval ships. It is also important to note that Turkish influence has been recently strengthened both economically and politically in Abkhazia, although the Turks haven't recognized it as an independent state. Turkey also actively supports Azerbaijan on the NagornoKarabakh issue, refuses categorically to recognize the fact of genocide of Armenians in 1915, intensifies the contacts with Turki fragments of the former Soviet 
Turkestan (the idea of the Great Turan), and actively supports the Crimean Tatar nationalism, as well as the Northern Caucasus and the Volga separatists in Russia. All these examples demonstrate the increasing Turkish influence in the post-Soviet region. At the same time, this situation seems fairly alarming for Russia, which is obliged to maintain its position in this region at least to maintain its own security.

Another important direction of geo-economic and geopolitical Turkish interests is Middle East. Despite the ProAmerican vector of Turkey's position on the Syrian issue, the degree of Turkish political independence is perceived with suspicion by the USA and Great Britain. Apparently, some reasons for the recent activization of the Turkish opposition are connected with the discontent of above-mentioned Anglo-Saxon countries. To a certain extent this discontent shows Turkey's unwillingness to intervene directly in the Syrian conflict and is only limited itself to indirect support for terrorist groups. However, Turkey showed that the degree of its geopolitical autonomy as a regional leader is large enough.

\subsection{Brazil: from regional dominance towards global influence}

There is also a group of regional powers, which influence in the world economy and in the world community in general, allows to speak about their prospects as full-fledged poles of the forming multipolar world. One of such ascending centers is Brazil, a South American giant with 200 million Portuguese-speaking population, which is considered a potential superpower of the XXI century. Nowadays being the largest population and area in South America, as well as throughout all Latin America, Brazil is currently the seventh economy in the world by nominal GDP and GDP based on purchasing power parity (2394 billion U.S. dollars by the end of 2012). Although the rate of growth of the Brazilian GDP in 2012 was only $1.3 \%$ (in $2010-7.5 \%$, in $2011-2.7 \%$ ), partly due to the general slowdown in the world economy, the economic crisis in the EU, an insignificant growth in the USA and certain weakness of domestic demand in Brazil itself, in general, the forecasts for the coming years for Brazil are quite positive. Unlike a number of other developing countries (including Russia), Brazil confidently has overcome the investment slowdown of the economic crisis. Already in 2011 the volume of FDI in the Brazilian economy had already exceeded the pre-crisis level of 2008 by almost 1.5 times. Moreover, according to "Forbes", in 201233 Brazilian multinational corporations entered the rating of 2 thousand world-largest MNCs that is, beyond all doubt, a very meaningful indicator of economic success of this country. At the same time, a marked worsening of internal political problems during last months, the information campaign against the President and social conflicts, probably inspired from outside, can obviously be correlated with the consistent line of the Anglo-Saxon center of influence on counteracting trends of independence and attempts to conduct their own foreign policy by new regional and global poles of geo-economic influence. There may be revealed the real limits of independence, under which global AngloAmerican predominant politic and economic power allows even such a powerful regional economic and political centers as modern Brazil to act and defend their interests. In the same way as afore-mentioned assessment of Western attempts to limit the independence of Turkey as a regional power, American policy towards Brazil clearly demonstrates the persistent reluctance and opposition to any, even prospective models of globalization, apart from those, which are known now as "Anglobalization" (Ferguson, 2003).

It is noteworthy that the economic conditions of regional powers' formation are not less diverse than their geographical dispersion. So, for example, Poland rose to the position of a regional leader on the ruins of the socialist camp, having transformed from a satellite to the rival of Russia. Many other states which have become regional powers today, in the second half of the twentieth century were the "Third world" countries. They were characterized by the weakness of geo-economic and geopolitical position (in terms of global Soviet-American dualistic hegemony), often unstable economy and political system, as well as incoherent economic policy.

Thereby, important consequences of global processes of the last quarter of this century (along with the collapse of the bipolar configuration and the world economic crisis) are the considerable increase of regional powers' role. Obviously, in contrast to the classical poles of the emerging multipolar world with global influence and all-embracing ambitions affecting the economic and political balance in different parts of the world, ascending regional powers have a bit localized areas of interest and influence. However, they demonstrate strengthening the second-order powers within the new configuration of the world economy in the XXI century. Certainly, the strong development of the regional powers in the modern world economy demonstrates the multilevel nature of the emerging economic and political multipolarity.

Thus, the current global instability of the world economy leads to the formation of a multipolar system. And in this regard, the need to strengthen the economic position of Russia as well as European Union and their transformation into major poles of the world economic and political system seem to be relevant and important. 


\section{Conclusions}

Thus, multilevel and multidimensional economic multipolarity is shaping under modern conditions. New global configuration will determine not only the main qualitative characteristics of the world economic system, but the alignment of forces and the hierarchy of economic and political centers of the world economy. Nevertheless, a noticeable gap between political and economic components of multipolarity is an important factor in the dynamics of the contemporary world. Though currently the economic hegemony of the United States and the traditional leaders of the capitalist world are significantly weakened by the dynamic growth of the developing countries, (first of all, by the leading countries of Asia), within the political sphere a multi-polar world is only at the stage of formation. One of the most important trends of the modern development of the world economic system is strengthening regionalization leading to integration groups around a powerful regional leader. Regionalization is one of the pillars of strengthening and accelerating the geoeconomic multipolarity's development. In general, within the framework of the world economic system these trends exist on the background of global uncertainty of future development of the geopolitical and geo-economic processes in the world. Despite strengthening multi-dimensional multipolarity, there are serious forms of political opposition to these processes from the USA and its main allies. Besides political reason of the confrontation between the defenders of the unipolarity, on the one hand, and the forces representing multipolar geo-economic trends, on the other hand, there are also purely economic aspects of uncertainty. First of all, they are connected with the problems of the world economy that have not been resolved due to the recent crisis, as, for example, a mismatch and unbelievable gap between the real and fictitious sectors of the economy. Moreover, the prospects of a number of potential centers of economic and political multipolarity are rather uncertain as well. This also applies to Russia that maintains the basis of its economic potential and heads the integration processes on the post-Soviet space. At the same time, Russia has the deep-rooted problems of economy encompassing its main industrial sectors and economic system which doesn't correspond to the current level of development in most developing countries. Beyond all doubt, this situation requires more effective modernization measures in Russia.

In general, the multilevel geo-economic multipolarity is an important feature of modern world economy. However, the contours of its future polycentric economic and political configuration are only outlined nowadays.

\section{References}

Adrian Croft. (2012). Cameron vows to block EU-wide Tobin tax.http://uk.reuters.com/article/2012/01/08/uk-britain-tax-idUKTRE80707 D20120108 (Accessed on February 2, 2013)

Brzezinski Z. (2012). Strategic vision: and the Crisis of Global Power. Basic Books. NY, pp. 213.

Chaumet M. (2013). Atterissageen perspective pour l'économieturque. www.pays-emergents.com/html/presse_pg.php?xx_texte_id=181 (Accessed on January 15, 2013)

Ferguson N. (2003). Empire: how Britain made the modern world. Allen Lane. London. pp. 417.

Global Development Horizons. Multipolarity: The New Global Economy. (2012). Washington: The International Bank for Reconstruction and Development. The World Bank,pp. 160.

Gulevich V. (2012). Visegrad Group gets ready for NATO summit. www.strategic-culture.org/news/2012/04/26/visegrad-group-getsready-for-nato-summit.html (Accessed on April 24, 2012)

Khudyakova L. (2012). International financial centers in the multipolar world. World economy and international relations, 1: 30-39.

Kondratov D. (2012). About Poland's prospects in the Eurozone. Economist, 9: 77-84.

Mulholland H. (2012). David Cameron backs referendum on Europe. www.guardian.co.uk/politics/2012/oct/09/david-cameron-backsreferendum-europe (Accessed on October 9, 2012).

Population totale de Turquie. (2013). Perspective Monde. Université de Sherbrooke.http://perspective.usherbrooke.ca/bilan/ servlet/ BMTendanceStatPays?codeTheme=1\&codeStat=SP.POP.TOTL\&codePays=TUR\&codeTheme $2=1 \&$ codeStat2=x\&codePays $2=T$ UR\&langue=fr (Access on April 30, 2013).

Sluka N. Global cities. Expert, 15. (2012). http://expert.ru/expert/2008/15/globalnue_goroda/ (Access on November 15, 2012).

Vasilyeva K. (2013). In 2013, the emerging economies of the world will come to the fore.Economy and life, 2: 3.

World Economic Outlook Database. International Monetary Fund. (2014). http://www.imf.org/external/pubs/ft/weo/2014/02/weodata/ weorept.aspx?sy=2013\&ey=2014\&scsm=1\&ssd=1\&sort=country\&ds=.\&br=1\&pr1.x=32\&pr1.y=4\&c=924\%2C111\&s=PPPGDP\&gr $p=0 \& a=($ Accessed on October 15, 2014). 
